\title{
ICE DYNAMICS AND THERMAL REGIME OF TAYLOR GLACIER, SOUTH VICTORIA LAND, ANTARCTICA
}

\author{
By P. H. RoBinson*
}

(Antarctic Research Centre, Department of Geology, Victoria University of Wellington, Wellington, New Zealand)

ABstract. Glaciological data collected from Taylor Glacier have been used to assess aspects of the dynamics and thermal regime of the glacier. Mass-balance studies suggest that the glacier is in near equilibrium. The thermal condition of the basal ice over much of the ablation area was calculated from estimates of the geothermal heat influx and measurements of near-surface ice temperatures, ice velocities, and ice thickness. It was found that, in as much as $50 \%$ of the lower ablation area, the basal ice may be melting.

RÉsumé. Dynamique de la glace et régime thermique du Taylor Glacier, South Victoria Land, Antarctique. Les données glaciologiques recueillies sur le Taylor Glacier ont servi à reconstituer les principaux traits de la dynamique et du régime thermique du glacier. Les études du bilan de masse montrent que le glacier est proche de l'équilibre. Les conditions thermiques de la glace basale sur une grande partie de la zone d'ablation ont été calculées à partir

\section{INTRODUCTION}

Lack of understanding of polar glacial processes and their glaciogenic products provided the impetus behind this study. Because of the inferred influence of Taylor Glacier in the past glacial history of Taylor Valley (Denton and others, 1971; Stuiver and others, 1981), the present glacier was used as a model for assessing the behaviour of outlet polar glaciers.

The understanding of sediment transport by glaciers requires a knowledge of the dynamics and thermal conditions of the ice itself. The dynamics of glacier ice are best expressed by the mass balance and the consequent glacier flow, whereas the thermal regime is controlled by the geothermal heat flux, the mean annual surface temperature, ice velocity, and ice thickness. These glaciological conditions are basic to the understanding of the processes involved in producing, moving, and releasing glacial sediment in the Taylor Glacier system (Robinson, 1982, unpublished). This paper presents glaciological data collected from Taylor Glacier between 1975 and 1978, and applies the data to assess the present dynamic and thermal regime particularly at the base of the glacier.

A large ice dome, inland of Taylor Glacier, acts as a centre of outflow. Localized flow off the eastern slopes of the dome drains into Skelton, Ferrar, Mackay, and Taylor Glaciers, with very restricted flow to Wright Upper and Victoria Upper Glaciers (Drewry, 1982). Taylor Glacier is almost $100 \mathrm{~km}$ long from ice divide to snout (Fig. 1a). The accumulation area lies west of the Transantarctic Mountains, covering over $650 \mathrm{~km}^{2}$ with a maximum elevation of $2450 \mathrm{~m}$. The ice divide is over $30 \mathrm{~km}$ west of the mountains and extends south-westward from Wright Upper Glacier in the north, then south-eastward to the Lashley Mountains in the south. In the lower glacier, the ablation area covers approximately $760 \mathrm{~km}^{2}$ and is over $60 \mathrm{~km}$ long.

\section{ICE DYNAMICS}

\section{Mass balance}

Mass-balance investigations require that a glacier be divided into two areas, one characterized by net

*Present address: Petroleum and Basin Studies, New Zealand Geological Survey, Lower Hutt, New Zealand. d'estimation du flux de chaleur géothermique, et de mesures des températures de la glace près de la surface, des vitesses et de l'épaisseur de la glace. On a trouvé que jusqu'à $50 \%$ de la zone d'ablation la glace basale pouvait être fondante.

Zusammenfassung. Eisdynamik und Wärmehaushall des Taylor Glacier, South Victoria Land, Antarktika. Glaziologische Daten, die am Taylor Glacier gewonnen wurden, dienten zur Bestimmung der Dynamik und des Wärmehaushaltes des Gletschers. Studien zur Massenbilanz zeigen, dass der Gletscher sich annähernd im Gleichgewicht befindet. Die thermischen Verhältnisse des Eises am Untergrund eines Grossteils der Ablationszone wurden aus dem geothermischen Wärmefluss, aus Messungen der oberflächennahen Temperatur sowie aus den Eisgeschwindigkeiten und -dicken berechnet. Es ergab sich, dass in bis zu $50 \%$ der unteren Ablationszone das Eis am Untergrund abschmelzen dürfte.

accumulation and the other by net ablation. Locating the zone of separation of these areas is rather difficult. Normally, at the end of the summer, a temperate glacier (as defined by Ahlmann (1935)) can be readily seen as two distinct areas, one snowcovered (where the winter accumulation has exceeded the summer ablation), and the other, exposed glacier ice (where the reverse is true). The line of separation is termed the equilibrium line $(E L)$. In polar
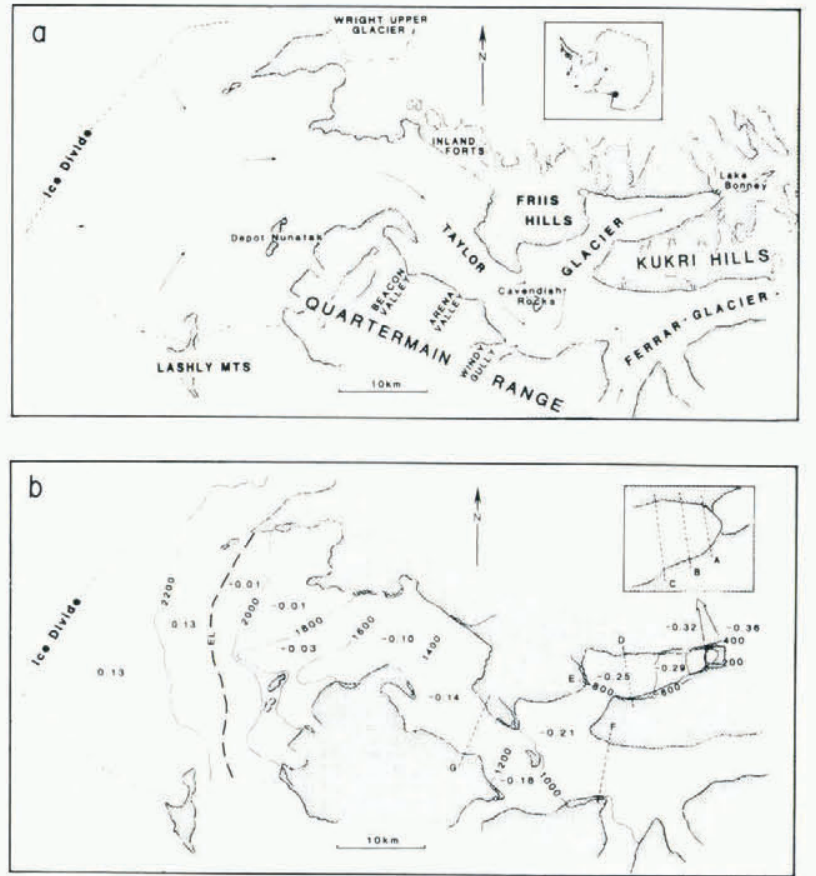

Fig. 1. a. Map of Tayzor Glacier, from the ice divide to the snout b. Map of Taylor Glacier depicting the area of averaged ablation and accumulation rates (in $m$ water year-1). Transverse 2 ines $A$ to $G$ indicate the approximate position of ablation and velocitypole lines. EL is the equilibrium line. Ice-surface contours are at $200 \mathrm{~m}$ intervals. 
regions, particularly in arid areas, the EL coincides with the boundary between dry snow and ice on the glacier surface (Müller, 1962; Fig. 3). Surface ice loss in polar glaciers, in both accumulation and ablation areas, is almost entirely by sublimation. The little melt that does occur is significant only in the lower part of the ablation area for 1-2 months in the summer. The approximate position of the EL for Taylor Glacier was determined from air photographs flown between 1957 and 1973 .

Measurement of accumulation. Accumulation along the route of the 1959-60 Victoria Land traverse was derived from 19 snow pits (Stuart and Heine, 1961) and averaged $0.16 \mathrm{~m}$ water year $\mathrm{r}^{-1}$ for the area inland from McMurdo Sound. The Taylor Glacier accumulation area is, on average, 200-300 m lower in elevation than the inland stations occupied by Stuart and Heine (1961); thus, a good approximation of net accumulation is $0.13 \pm 0.02 \mathrm{~m}$ water year ${ }^{-1}$, or $0.03 \mathrm{~m}$ water ${ }^{\star}$ less than the averaged accumulation obtained from the Stuart and Heine (1961) inland snow pits.

Measuement of ablation. Ablation occurs by surface melting, sublimation, and cliff ablation and calving. Surface ablation was measured at 62 pole sites and extrapolated to cover the entire ablation area of Taylor Glacier. The poles were placed in seven lines transverse to the glacier flow (Fig. 1b).

The close spacing of 1 ines across the snout $(A-C)$ was considered critical because of high ice-surface relief. Close spacing of the poles towards the margin enabled refined measurement of ablation, which was assumed variable due to the effects of snow drifting, shading, and high melt run-off.

The rate of ice ablation was obtained from the difference between the height of a pole measured on two separate occasions. The difference for measurements at the beginning and end of the measurement year (in metres) was converted to water-equivalent (m water) balance. Monitoring ablation for Taylor Glacier covered the period December 1975 to October 1978. The most complete ablation record for any one year was obtained during 1976 and 1977 (Table I). The other measurements, although incomplete, indicate similar ablation rates for the 3-year monitoring period. A mass balance was computed for the 1976-77 measurement year.

An estimate of mass balance. The loss of ice from Taylor Glacier by surface ablation was calculated by assuming that ablation rate is a linear function of elevation. The average ablation across 1 ines $A$ to $G$ for the 1976-77 year was calculated, and a linear regression of ablation against elevation obtained $(r=-0.87)$. The regression equation was then used to estimate the total ablation down-glacier of the equilibrium line. For the calculation, the ablation area was subdivided using the $200 \mathrm{~m}$ contours on the U.S.G.S. 1:250 000 Taylor Glacier Sheet (ST 57-

$60 / 5)$. The area between the contours was planimetered and multiplied by the average ablation determined at the elevation midpoint on the regression line (Fig. 2). The derived volumes were then summed and converted to a mass loss for the ablation area for the measurement year. The total accumulation expressed as a mass gain was obtained by multiplying the estimated average accumulation $\left(0.13 \mathrm{~m}\right.$ water year $\left.{ }^{-1}\right)$ by the area of accumulation as defined by the ice divide (from Drewry, 1982) and the EL. Summing the mass loss and mass gain gives a mass balance (Table II) for the glacier measurement year.

* An estimate of the decreasing sublimation with elevation in the Taylor Glacier ablation area $(0.01 \mathrm{~m}$ water $(100 \mathrm{~m})^{-1}$ elevation) was used to estimate annual ablation (not including drift loss) in the accumulation area, where melting is absent.
TABLE I. MEASURED ICE-SURFACE LOWERING BY ABLATION (m WATER year ${ }^{-1}$ ) ON TAYLOR GLACIER AT LINES A TO G FOR THE MEASUREMENT YEAR, NOVEMBER 1976 - NOVEMBER 1977. THE ESTIMATED ERROR ON ABLATION MEASUREMENT IS $7 \%$

$$
\text { Line Average ablation }
$$$$
\mathrm{m} \text { water }
$$

$\begin{array}{ll}\text { A } & 0.44 \\ \text { B } & 0.39 \\ \text { C } & 0.47 \\ \text { D } & 0.36 \\ \text { E } & 0.22 \\ \text { F } & 0.11 \\ \text { G } & 0.16\end{array}$

The estimated accumulation for the Taylor Glacier accumulation area is $84.9 \times 10^{6}$ tonnes for the measurement year 1976-77. However, additional ice input comes from Ferrar Glacier. Ice discharge through the crosssection beneath line $F$ is calculated at $3.5 \times 106$ tonnes year-1, and the estimated discharge through Windy Gully is $0.6 \times 10^{6}$ tonnes year ${ }^{-1}$. $^{*}$ Thus, the estimated ice gain for Taylor Glacier for the measurement year is $89.0 \times 10^{6}$ tonnes.

The estimated ice loss from the Taylor Glacier ablation area for the same measurement year is $79.5 \times$ $10^{6}$ tonnes and includes an estimate of $2.8 \times 10^{6}$ tonnes from ice-cliff ablation and calving. The icecliff ablation rate is an average of the ice-surface ablation between lines $A$ and $G\left(0.25\right.$ m water year $\left.r^{-1}\right)$, and represents an annual mass loss of $0.5 \times 10^{6}$ tonnes for the entire cliffed margin of Taylor Glacier. The

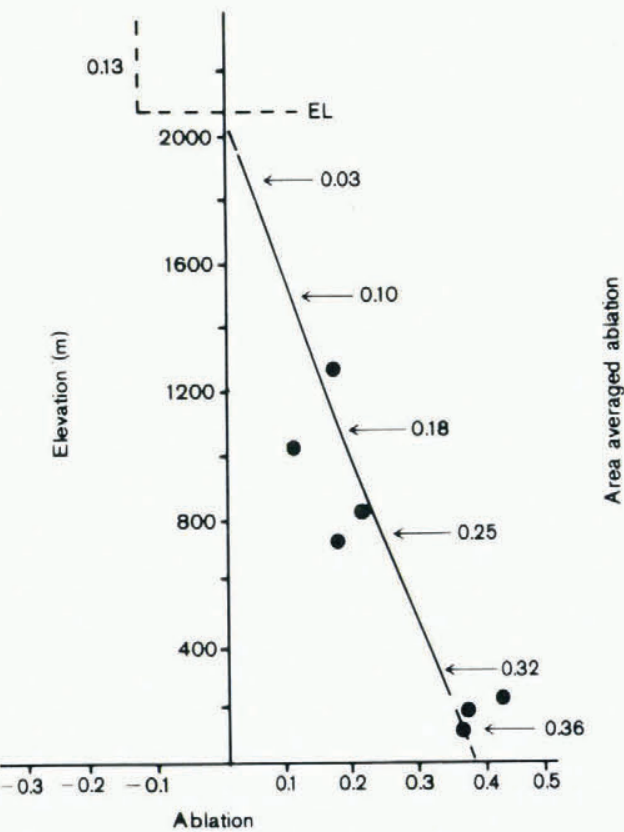

Fig. 2. Ablation, in metres of water equivalent

( $m$ water), plotted against elevation ( $m$ a.s.l.), with a reyression line (solid) through the plots of average measured ablation for lines $C$ to $G(\bullet)$, and fixed at the equilibrium line. The area-averaged ablation is determined from the regression line. $0.13 \mathrm{~m}$ water is an estimate of the average accumulation for the entire accumulation area (accumulation is negative ablation).

* Ice discharge through Windy Gully is calculated from estimates of the ice cross-sectional area ( $0.15 \pm$ $0.09 \times 10^{6} \mathrm{~m}^{2}$ ) and the average velocity of the ice column $\left(c .2 .4 \pm 1.6 \mathrm{~m} \mathrm{year}^{-1}\right)$. 
ice-cliff calving was determined from the size and extent of the ice-margin avalanche apron at the beginning of summer (after Bull and Carnein, 1970). The avalanche apron, averaging $2 \mathrm{~m}$ thick and extending $9 \mathrm{~m}$ from the ice cliff, skirts almost $140 \mathrm{~km}$ of the glacier margin, and represents an annual mass loss of $2.3 \times 10^{6}$ tonnes from the ablation area.

The errors involved in balancing glacier mass are large and are attributable to definite sources: (1) defining the positions of the ice divide and equilibrium line; (2) determining glacier surface areas; (3) calculating ice-surface and ice-cliff ablation; and (4) estimating local accumulation from regional averages. These errors are random and are assessed by calculation and estimate, and expressed as a percentage. For Taylor Glacier the mass gain has a $19.7 \%$ error* and the mass loss a $7.2 \%$ error.t Thus, the net mass gain of $9.5 \times 10^{6}$ tonnes computed for the year $1976-77$ is $10.7 \%$ of the mass gain and within the calculated error.

Because of the large variability in mass balance, it is not possible accurately to deduce the equilibrium condition of Taylor Glacier. However, no visible change in the position of the Taylor Glacier terminal face was observed during this study, or between the years 1913 and 1960 (Péwe and Church, 1962). For the purpose of this study, Taylor Glacier is considered to be in balance, within the stated limits of error.

Glacier flow

Surface velocity. Taylor Glacier does not appear to have a simple flow pattern. Nevertheless, a reasonable approximation of the pattern was obtained from the surveyed lines ( $A$ to $G$ ). Horizontal velocity was measured, while the vertical component of velocity was assumed equal to the measured ablation rate.

TABLE I I. NET MASS BALANCE FOR TAYLOR GLACIER FOR THE MEASUREMENT YEAR, NOVEMBER 1976 - NOVEMBER 1977. ERROR LIMITS FOR MASS GAIN ARE $\pm 20 \%$ AND FOR MASS LOSS ARE $\pm 7 \%$

$$
\times 10^{6} \text { tonnes year }{ }^{-1}
$$

Negative balance of ice surface below EL

$$
76.7 \pm 5.4
$$

Negative balance of icecliff face

$$
0.5 \pm 0.1
$$

$$
2.3 \pm 0.2
$$

Positive balance of ice surface above EL

$$
84.9 \pm 16.1
$$

Positive balance of Ferrar Glacier inputs

$$
4.1 \pm 1.5
$$

$$
\text { Ice gain } \quad 89.0 \pm 17.6
$$

The net mass gain for the whole glacier is $(9.5 \pm$ $23.3) \times 10^{6}$ tonnes.

* Errors in ice gain are calculated from a $19 \%$ error in estimating the accumulation rate, and a $36 \%$ error for the estimate of ice input from Ferrar Glacier.

t Errors in ice loss are a composite of a $7 \%$ error in calculating the volume of surface ice lost and a $10 \%$ error in estimating ice loss by cliff ablation and calving.
Horizontal velocity measured between December 1975 and January 1978 is illustrated in Figure 3 and summarized in Table III. In each line, the velocity changes little across the central part of the glacier but decreases rapidly towards the sides. This is attributed to ice drag against the valley sides and decrease in ice thickness away from the glacier centre line, thus altering the thermal condition of the basal ice. The variation in ice velocity across the glacier is enhanced where the width is only four or five times the centre-line ice thickness (e.g. 1 ines $E$ and $G$ ). However, the across-glacier velocity profiles for 1 ines $A$ to $D$ and $F$ are less variable, probably due to wide ice cross-sections beneath these lines.

Flow rates measured at 1 ine $F$ are related to ice influx from Ferrar Glacier. The majority of the Ferrar
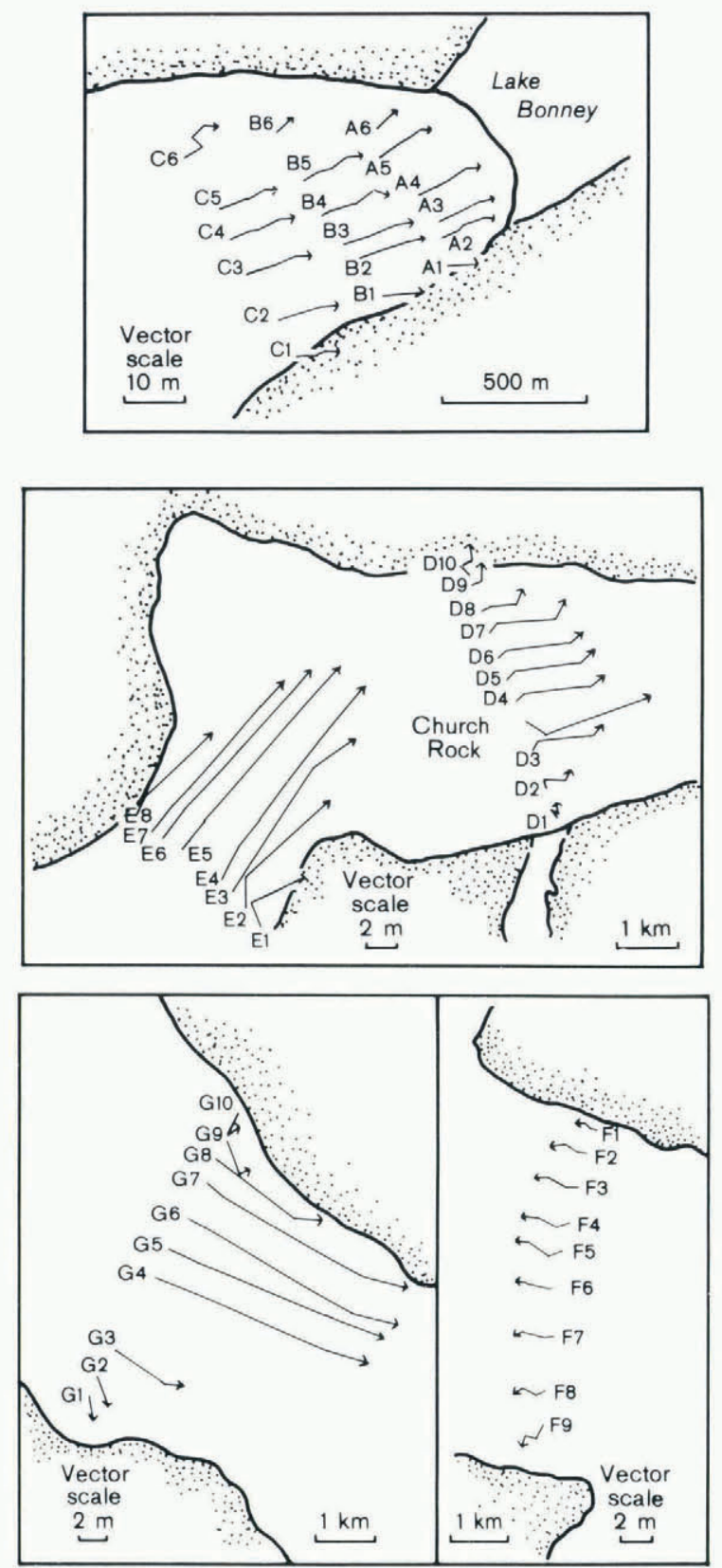

Fig. 3. Ice-surface movement for the ablation area of Taylor Glacier (lines $C$ to G), measured between December 1975 and January 1978, and expressed as vectors of ice motion in a horizontal direction (in metres). 
TABLE III. MAGNITUDE OF SURFACE-ICE MOVEMENT (m year ${ }^{-1}$ ) FOR TAYLOR GLACIER DURING THE MEASUREMENT YEAR, NOVEMBER 1976 - NOVEMBER 1977. ESTIMATED SURVEYING ERROR LIMITS ARE $\pm 0.1 \mathrm{~m}$ FOR LINES A, B, C, F, AND $G, A N D \pm 0.2 m$ FOR LINES D AND $E$

$\begin{array}{cccr}\text { Pole } & \begin{array}{c}\text { Velocity } \\ \text { m year-1 }\end{array} & \text { Pole } & \begin{array}{r}\text { Velocit } \\ \text { m year }\end{array} \\ \text { A1 } & 2.0 & \text { D1 } & 1.2 \\ \text { A2 } & 4.4 & \text { D2 } & 1.9 \\ \text { A3 } & 4.4 & \text { D3 } & 4.5 \\ \text { A4 } & 4.8 & \text { Church Rock } 7.1 \\ \text { A5 } & 4.4 & \text { D4 } & 5.6 \\ \text { A6 } & - & \text { D5 } & 5.6 \\ & & \text { D6 } & 5.3 \\ \text { B1 } & 3.2 & \text { D7 } & 5.1 \\ \text { B2 } & 5.1 & \text { D8 } & 2.9 \\ \text { B3 } & 5.2 & \text { D9 } & 1.7 \\ \text { B4 } & 5.4 & \text { D10 } & 1.5 \\ \text { B5 } & 4.9 & & \\ \text { B6 } & - & \text { E1 } & 3.7 \\ & & \text { E2 } & 8.1 \\ \text { C1 } & 2.9 & \text { E3 } & 11.3 \\ \text { C2 } & 4.1 & \text { E4 } & 13.9 \\ \text { C3 } & 5.6 & \text { E5 } & 14.0 \\ \text { C4 } & 5.6 & \text { E6 } & 12.9 \\ \text { C5 } & 5.4 & \text { E7 } & 11.4 \\ \text { C6 } & 5.0 & \text { E8 } & 6.2\end{array}$

uh

$\alpha$

B

$\theta_{h}$

$\theta_{\mathrm{S}}$

$k_{i}$

$\rho$

$\tau_{\mathrm{b}}$

$\left(\frac{\delta \theta}{\delta_{h}}\right)_{\mathrm{b}}$ velocity of a layer at height $h$ above the bed.

slope of ice surface.

measure of the proportionality of strain-rate to stress.

ice temperature at height $h$ above the glacier bed.

surface-ice temperature (mean annual surface temperature).

thermal diffusivity of ice

(41.6 $\mathrm{m}^{2}$ year ${ }^{-1}$ for Taylor Glacier).

density of ice.

basal shear stress.

temperature gradient in the basal ice.

In the absence of field measurements, horizontal englacial velocities for Taylor Glacier were theoretically determined using

$$
u_{s}-u_{h}=\frac{2 \beta(\rho g)^{n}\left(\sin ^{n} \alpha\right)(H-h)^{n+1}}{n+1}
$$

Glacier ice flows to the north-east, down-valley. However, a small amount moves north-west into Taylor Glacier. The low surface velocities measured at line F probably result from compressional flow between Ferrar and Taylor Glaciers, as the former flows into the latter. Generally, however, measured surface velocities for Taylor Glacier exhibit ice under extensional flow. Such patterns of ice-surface velocity enable theoretical approximations of the englacial and basal components of ice flow.

Englacial and basal velocity. If the basal ice of a glacier is at pressure melting, a part of the measured surface velocity is likely to result from ice slip over the bed. To obtain the amount of basal slip, assuming temperate ice conditions at the glacier sole, an estimate of the englacial velocity is required. This allows basal velocity to be estimated as the difference between the surface velocity and englacial velocity.

Summary of symbols

$\dot{B}$

$F(x)$

$g$

$h$

$K_{j}$

$n$

$\bar{u}$

$u_{\mathrm{s}}$ ablation rate.

Dawson's integral.

gravitational acceleration.

total ice thickness.

height of a layer of ice above the glacier bed.

thermal conductivity of ice.

flow-law exponent $(n=4.2$ for Taylor Glacier; personal communication from W. Robinson, 1978).

heat produced in basal ice $\left(Q_{\mathrm{b}}=\overline{u^{\top}} \mathrm{b}\right)$.

geothermal heat flow.

mean of basal-ice velocity.

surface-ice velocity. which is derived from the generalized flow law of ice (Nye, 1951), where $\beta$ and $n$ are constants.

Before reliable englacial velocities can be determined from Equation (1), specific values of $\beta$, which
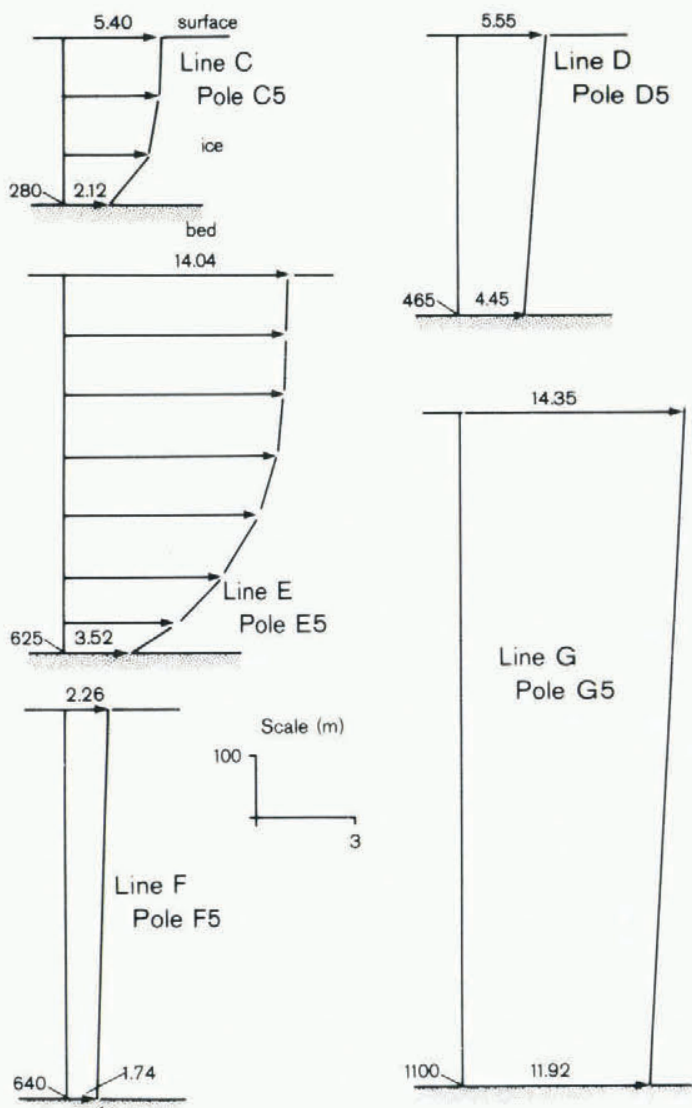

Fig. 4. Theoretically derived englacial horizontal velocity profiles for centre-line poles in lines $C$ to $G$. Horizontal velocity is expressed in $m^{\text {year-1; }}$ ice thickness in metres. 
is dependent on temperature, are required. Ice temperatures in Taylor Glacier probably differ by 15 to $25 \mathrm{deg}$ between the glacier surface and the sole. Under such conditions, the value of $B$ is a function of position and could vary by nearly two orders over such temperature ranges (Glen, 1955). Since the flow law involves many simplifying assumptions and because of the uncertainty of the value of parameter $\beta$, the velocity profiles derived from Equation (1) are approximations.

Figure 4 presents the calculated englacial and basal velocities beneath the centre poles of lines $C$ to $G$. The basal slip is large relative to the internal flow; presumably, this is the result of low basal shear stresses which result from high hydrostatic pressures. In areas where wet-base conditions are inferred to occur, the theoretically derived englacial velocity represents, on average, about $40 \%$ of the measured horizontal velocity at the ice surface. The remainder is taken up in basal slip and, therefore, is the main process contributing to horizontal ice movement in these areas of Taylor Glacier.

\section{THERMAL REGIME}

Temperature modelling

The behaviour of most glaciers is critically dependent on temperature. The temperature distribution through a glacier is mainly determined by geothermal heat flow, mean annual surface temperature, ice thickness, the vertical component of ice velocity, and the heat generated by basal sliding and ice deformation.

When temperature modelling, it is normally assumed that the glacier is close to dynamic equilibrium; this has not been conclusively proved but is assumed for Taylor Glacier. The above features are reviewed and values for Taylor Glacier are found.

Geothermal heat flow. An estimate of the geothermal heat entering the base of Taylor Glacier was obtained from existing measurements in the region. Decker and Bucher (1977) presented data on sub-surface temperatures, thermal conductivities, and heat-flow values from permafrost sediment and bedrock. Preliminary calculations indicated a heat flow of $0.088 \mathrm{~J} \mathrm{~m}^{-2} \mathrm{~s}^{-1}$ for Dry Valley Drilling Project (DVDP) hole 6, drilled in granite at Lake Vida. This is more than twice the heat flow measured in other continental crustal terrains (e.g. Canadian shield with a heat flow of $0.038 \mathrm{j} \mathrm{m}^{-2} \mathrm{~s}^{-1}$ (Clark, 1966)).

The plutonic terrain beneath Taylor Glacier is similar to that around Lake Vida and therefore it seems reasonable to assume the same heat-flow value, particularly since Decker (1978) explained the high heat flux by a convective model on a regional scale.

Mean annual surface temperature. It is commonly accepted that the temperature measured between 15 and $20 \mathrm{~m}$ beneath the glacier surface is a good approximation of the mean annual air temperature (MAAT) (Paterson, 1981, p. 188). Calculation for Taylor Glacier showed that seasonal temperature changes are not detectable below a depth of $20 \mathrm{~m}$ (Robinson, unpublished) and that, at $17 \mathrm{~m}$, the amplitude of change is unlikely to exceed 0.1 deg (Keys, unpublished). Therefore, the MAAT can be approximated by a measure of the mean annual surface temperature (MAST) at $17 \mathrm{~m}$ depth.

Measuring the MAST over the entire glacier is impractical. However, as a first approximation, it is assumed that the MAST decreases in a more or less linear fashion with increasing elevation (Hooke, 1977), and the rate of decrease is termed the lapserate. In association with a measured MAST at a known elevation, the lapserate can be used to infer an approximate surface-ice temperature for different parts of a glacier or ice sheet.

A number of lapse-rates have been recorded for
Antarctica. Budd and others (1971) obtained a lapserate of approximately $1.0 \mathrm{deg}(100 \mathrm{~m})^{-1}$ inland of the Wilkes Coast, and Taylor (1965) computed a lapse-rate of $0.8 \mathrm{deg}(100 \mathrm{~m})^{-1}$ on a traverse to the South Pole. Bentley and others (1964) calculated a much lower lapse-rate at $0.35 \mathrm{deg}(100 \mathrm{~m})^{-1}$ for traverses that covered large areas but small ranges in elevation in West Antarctica.

Lapse-rates in the Dry Valleys area lie between the extremes quoted above. Calculations from the temperature and elevation measurements for Meserve Glacier (Hughes, 1971; Holdsworth, 1974) give a lapserate of $0.6 \mathrm{deg}(100 \mathrm{~m})^{-1}$. From surface ice-temperature measurements at different elevations on Taylor Glacier (Robinson, unpublished) a lapse-rate of $0.4 \pm$ $0.05 \mathrm{deg}(100 \mathrm{~m})^{-1}$ was obtained. The latter is consistent with lapse-rates calculated by Keys (unpublished) from meteorological observations for the McMurdo Sound region.

At the snout of Taylor Glacier, the best fit between measured and calculated crevasse temperatures gives a MAST of $-17.0^{\circ} \mathrm{C}$ at $17 \mathrm{~m}$ beneath the ice surface, whereas at 1 ines $F$ and $G$ the $17 \mathrm{~m}$ temperatures are $-20.1^{\circ} \mathrm{C}$ and $-21.5^{\circ} \mathrm{C}$, respectively. These ice temperatures are measured at known elevations, hence MAST values for any known elevation on Taylor Glacier can be estimated by extrapolation and interpolation using the calculated lapse-rate.

Ice thickness. Ice thickness for Taylor Glacier was obtained from gravity (Stern, 1978) and radio echosounding (Calkin, 1974; Drewry, 1982) surveys, and is presented as simplified transverse profiles (Fig. 5 ).

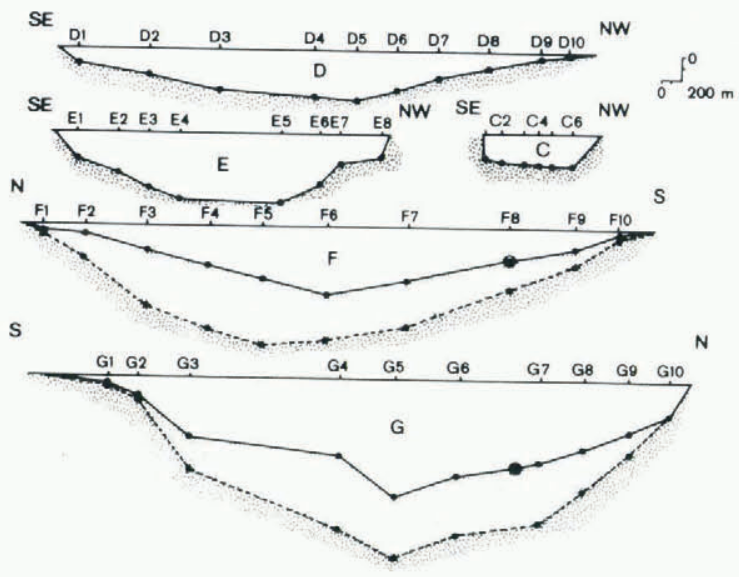

Fig. 5. Profiles of ice cross-sections beneath lines $C, D, E, F$, and $G$, Taylor Glacier (adapted from Stern (1978)). Approximate sediment thickness is included in the profiles at lines $F$ and $G$. The intersection of gravity and radio echo-sounding profiles is marked (-) on profiles $F$ and $G$.

Both Calkin (1974) and Drewry (1982) wrote of the subice terrain as bedrock. However, Stern (1978) found that the combined gravity and radio echo-sounding data for lines $F$ and $G$ were inconsistent with any simple two-layer model. The data required a third layer of density between that of ice and bedrock. The most reasonable value was the density of unconsolidated sediment $\left(2.2 \mathrm{Mg} \mathrm{m}^{-3}\right)$. Stern used this value in a three-layer model and calculated the maximum thickness of subglacial sediment to be $613 \mathrm{~m}$ for line $F$, and $563 \mathrm{~m}$ for line $\mathrm{G}$, with the maximum thickness of ice beneath these 1 ines as $640 \mathrm{~m}$ and $1110 \mathrm{~m}$, respectively.

At $l$ ines $C, D$, and $E$, where there are no echosounding control data for the corresponding gravity profiles, Stern (1978) explained the gravity profiles entirely by changes in ice thickness and assumed no sub-ice sediment. 
Vertical ice velocity. Ice velocity can be resolved into two components, horizontal and vertical. Although horizontal velocities are almost without exception the larger, the temperature gradient produced by horizontal velocity is quite small. A far more important process of heat transfer through an ice mass results from the vertical component of velocity.

Vertical velocities for Taylor Glacier were obtained from ablation rates in the ablation area (see Table I). The maximum vertical velocity $\left(0.56 \mathrm{~m} \mathrm{year}^{-1}\right)$ occurs $400 \mathrm{~m}$ from the snout. An up-glacier progressive decrease in vertical velocity is assumed from the decrease in the averaged ablation ( 1 ine $\mathrm{C}, 0.47 \mathrm{~m}$ year $\mathrm{r}^{-1}$ line $D, 0.36 \mathrm{~m} \mathrm{year}^{-1}$; line $E, 0.22 \mathrm{~m}$ year $^{-1}$;

line $F, 0.11 \mathrm{~m}^{\text {year }} \mathrm{r}^{-1}$; and 1 ine $G, 0.16 \mathrm{~m}^{\text {yea }} \mathrm{r}^{-1}$ ) and this velocity is assumed to decrease linearly with depth.

No assessment of the downward velocity component in the accumulation area was attempted, as the accumulation rate for Taylor Glacier $\left(0.13 \mathrm{~m}^{2}\right.$ water year $\left.{ }^{-1}\right)$ is only an approximation and any temperature profiling for this area, using a single value of vertical velocity, would be misleading.

Internal heat generation. Because horizontal velocity decreases with depth, there is a shear deformation in the horizontal direction. Calculation of this deformation for Taylor Glacier indicates that upwards of $60 \%$ of the shear occurs just above the bed (see Fig. 4). All the frictional heat resulting from the deformation is assumed to be released at the base of the glacier.

In the lower ablation area of Taylor Glacier (down-glacier of line E), theoretical calculations show that the frictional heat produced in the basal ice $\left(Q_{b}\right)$ contributes between 6 and $12 \%$ to the total heat generated (Table IV). This extra heat input is greatest at the centre and decreases towards the margin. For lines $C, D$, and $E$, the calculated malimum increase in basal ice temperature due to heat from basal ice deformation is $1.5 \mathrm{deg}$. Beneath lines $F$ and $G$ the addition of internally generated frictiona heat to the geothermal heat input at the ice base is calculated to increase the total heat by approximately 24 and $19 \%$, respectively (Table IV), which is likely to increase basal ice temperatures by a maximum of 4.5 deg.

TABLE IV. CALCULATIONS OF FRICTIONAL HEAT $\left(Q_{b}\right)$ AND TOTAL HEAT GENERATED $\left(q_{q}+q_{b}\right)$ IN THE BASAL ICE OF TAYLOR GLACIER BENEATH THE CENTRE OF LINES C TO G

$$
\text { Line }
$$$$
\begin{array}{lllll}
C & D & E & F & G
\end{array}
$$

Qb

$\begin{array}{lllll}0.0073 & 0.0055 & 0.0120 & 0.0278 & 0.0207\end{array}$

$\left(\mathrm{J} \mathrm{m}^{-2} \mathrm{~s}^{-1}\right)$

$Q_{g}+Q_{b}$

$$
\begin{array}{lllll}
0.0953 & 0.0935 & 0.1000 & 0.1158 & 1.1087
\end{array}
$$

$\left(\mathrm{J} \mathrm{m}^{-2} \mathrm{~s}^{-1}\right)$

$\left(Q_{\mathrm{g}}\right.$ of $0.0880 \mathrm{~J} \mathrm{~m}^{-2} \mathrm{~s}^{-1}$ is assumed for Taylor Glacier.)

\section{Calculation of basal ice temperatures}

A number of mathematical models were reviewed for calculating Taylor Glacier basal-ice temperatures (Robin, 1955; Budd and others, [1970], 1971;

Philberth and Federer, 1971; Hooke, 1976, 1977; Jones, 1978). The models of Budd and others, Philberth and Federer, and Jones were developed from Robin (1955) for ice-temperature modelling in accumulation areas. As the implicit requirement is that the accumulation rate be positive, this generally restricts the direct application of these models to regions above the equilibrium line. However, Robin's model is readily modified for use in ablation areas:

$\theta_{\mathrm{s}}-\theta_{h}=\left(\frac{\delta \theta}{\delta h}\right)_{\mathrm{b}} \sqrt{\frac{2 \kappa_{\mathrm{i}} H}{\dot{B}}}\left[\mathrm{~F}\left(\sqrt{\frac{\dot{B} H}{2 \kappa_{\mathrm{i}}}}\right) \exp ^{\frac{B H}{2 \kappa_{\mathrm{i}}}}-\mathrm{F}\left(h \sqrt{\frac{\dot{B}}{2 \kappa_{\mathrm{i}} H}}\right) \exp ^{\frac{B h^{2}}{2 \kappa_{i} H}}\right]$.

Modification of the Budd and others' model for use in the ablation area was presented by Hooke (1976). Comparisons were made between ice temperatures derived from Hooke's modification and the modification of Robin's model for this study. In both the Hooke and modified Robin models, the vertical velocity is assumed to decrease linearly with depth. However, Hooke's model accounts for internal heat generation from shear deformation at the glacier base, and the horizontal temperature gradient throughout the ice mass.

In Taylor Glacier, the heat generated from shear deformation could increase the basal heat input by $6-24 \%$ when added to the geothermal heat flow (see Table IV). Such additional heat is likely to be substantially greater than any cooling effects produced by horizontal advection in ice. Since Hooke's model accounts for both internal heat generation and horizontal cooling (or warming), and basal temperatures derived using this model are warmer than those derived from the modified Robin model, it is assumed that the heat produced by internal deformation exceeds that from horizontal cooling. The lower temperatures derived using the modified Robin model indicate only the minimum approximate extent of the melting zones beneath Taylor Glacier (Fig. 6). The study of basalice temperatures in Taylor Glacier was carried out to

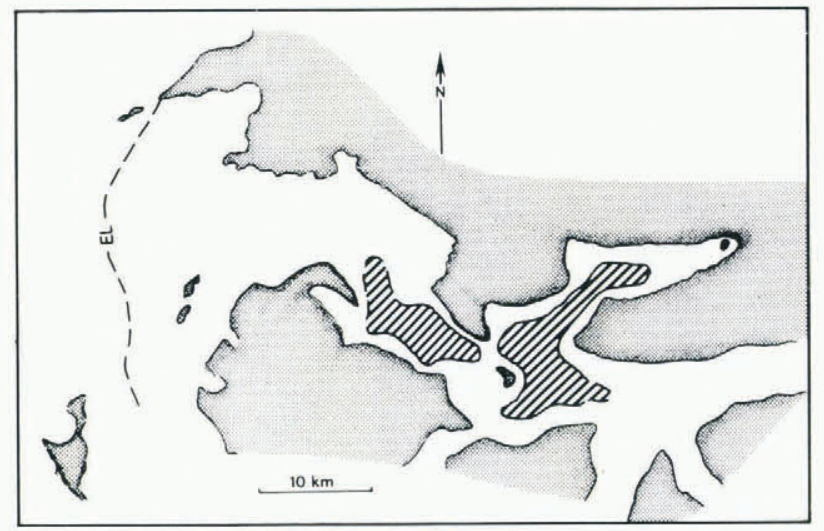

Fig. 6. Map of areas of theoretically derived basal temperatures at $0^{\circ} \mathrm{C}$ (hachured) for the lower ablation area, Taylor Glacier.

determine the presence of temperate ice and melting zones at the glacier sole. Therefore, it is sufficient to use a simplified model (Robin, 1955) that broadly delineates basal-ice thermal zones. This model probably underestimates the basal-ice temperature in Taylor Glacier and thus the melting zones detected will be underestimated, while the model of Hooke (1976) gives larger zones of basal-ice melting.

The greatest errors were assumed in assessing vertical velocities and basal heat gradients. Therefore, the sensitivity of the basal thermal regime to changing these input variables was assessed: (i) when vertical velocities equivalent to the ablation rate and zero were separately applied to Equation (2); and (ii) when the basal heat was reduced by neglecting the frictional heat produced. By separately reducing both vertical velocity and basal heat influx, the area of basal melting is effectively reduced. For example, if the vertical velocities were neglected (i.e. 
$\dot{B}=0$ in Equation (2)) but equilibrium in the temperature profiles was maintained, the heat flow through the basal ice beneath 1 ines $E, F$, and $G$ would require only 80,79 , and $49 \%$, respectively, of the estimated total geothermal heat supplied to the glacier sole. Such a heat reduction would just maintain the basal ice at $0^{\circ} \mathrm{C}$. Any further heat loss would result in freezing at the base.

The effect of reducing the geothermal heat influx while maintaining the vertical velocity was also considered. Under such circumstances, a 9 to $79 \%$ decrease in the geothermal heat flow beneath $C$ to $G$, respectively, is required before basal-ice melting is prevented beneath all the lines (assuming the temperature equilibrium is maintained throughout the ice column).

Figure 6 illustrates that about $50 \%$ of the lower ablation area of Taylor Glacier may be at pressure melting and therefore can be expected to behave as temperate ice. The area is a minimum, for the reasons already outlined, and because the glacier probably passes over extensive salt deposits (Keys, unpublished), which have the effect of depressing the freezing-point of the basal ice and thereby extending basal melt. Further investigation may reveal similar large areas of basal melting beneath the upper ablation area and into the accumulation area, extending the zones of melting beyond the restricted distribution discussed here and beyond the sub-ice lakes described by Drewry (1982) for the ice sheet west of Taylor Glacier.

\section{SUMMARY}

The temperature distribution in the basal ice for the ablation area of Taylor Glacier was obtained from the following data:

1. Mass loss from surface ablation (measured average $100 \mathrm{~kg} \mathrm{H}_{2} \mathrm{O} \mathrm{m}^{-2}$ year-1) and ice-cliff ablation (estimated average $1000 \mathrm{~kg} \mathrm{H}_{2} \mathrm{O} \mathrm{m}^{-2}$ year ${ }^{-1}$ ) for the ablation area, and mass gain from accumulation (estimated average $130 \mathrm{~kg} \mathrm{H}_{2} \mathrm{O} \mathrm{m}^{-2} \mathrm{year}^{-1}$ ) and ice input from Ferrar Glacier (estimated total $4.1 \times$ $10^{6}$ tonnes $\mathrm{H}_{2} \mathrm{O}$ year ${ }^{-1}$ ) indicates that Taylor Glacier is close to mass-equilibrium conditions.

2. Horizontal surface-ice velocity measured for the Taylor Glacier ablation area averages $6.1 \mathrm{~m}$ year $^{-1}$, with a maximum of $14.4 \mathrm{~m}$ year $^{-1}$ (line G). The vertical surface-ice velocity, estimated from the measured rate of surface ablation, averages $0.24 \mathrm{~m}$ year $^{-1}$, with a maximum of $0.56 \mathrm{~m} \mathrm{year}^{-1}$ (in line C). In areas of inferred basal melting, theoretically determined englacial velocity profiles indicate that between 25 and $83 \%$ (and on average $60 \%$ ) of the surface velocity is the result of basal slip.

3. A regional geothermal heat flow of 0.088 $\mathrm{J} \mathrm{m}^{-1} \mathrm{~s}^{-1}$ was used to approximate the heat flow into the base of Taylor Glacier.

4. Mean annual surface temperatures at the snout and equilibrium line of Taylor Glacier are $-17.0^{\circ} \mathrm{C}$ and $24.6^{\circ} \mathrm{C}$, respectively. These data were obtained from crevasse temperatures and extrapolation of drill-hole temperatures. A temperature lapse-rate of $0.40 \pm 0.05 \mathrm{deg}(100 \mathrm{~m})^{-1}$ was also determined.

5. Ice thickness, obtained from gravity survey and radio echo-sounding data, is on average $400-500 \mathrm{~m}$ in the ablation area. However, in restricted subglacial depressions the ice thickness exceeds $1000 \mathrm{~m}$.

Assuming steady-state conditions, the distribution of basal temperatures for Taylor Glacier, determined from the above data, indicates that as much as $50 \%$ of the basal ice in the lower ablation area may be melting.

\section{ACKNOWLEDGEMENTS}

This study formed part of a doctoral dissertation and the author acknowledges with thanks the supervision and support of Dr P.J. Barrett, Antarctic Research Centre, Victoria University of Wellington. Financial support for this study was provided by a university post-graduate scholarship from Victoria University of Wellington. Logistic and field support was provided by the Antarctic Research Centre, the New Zealand Antarctic Division (DSIR), and the United States National Science Foundation. Special thanks are due to DrS P.J. Barrett and G.S. Boulton for critically reviewing parts of the manuscript.

\section{REFERENCES}

Ahlmann, H.W. 1935. Contribution to the physics of glaciers. Geographical Journal, Vol. 86, No. 2, p. 97-113.

Bentley, C.R., and others. 1964. Physical characteristics of the Antarctic ice sheet, by C.R. Bentley, R.L. Cameron, C. [B.B.] Bull, K. Kojima, and A.J. Gow. Antarctic Map Folio Series (New York, Anerican Geographical Society), Folio 2.

Budd, W.F., and others. [1970.] The extent of basal melting in Antarctica, by W.[F.] Budd, D. Jenssen, and U. Radok. Polarforschung, Bd. 6, Jahrg. 39, $\mathrm{Nr} .1$, p. 293-306.

Budd, W.F., and others. 1971. Derived physical characteristics of the Antarctic ice sheet. Mark 1, by W.F. Budd, D. Jenssen, and U. Radok. Melbourne, University of Melbourne. Meteorology Dept. (University of Melbourne. Meteorology Dept., Publication No. 18.)

Bull, C.B.B., and Carnein, C.R. 1970. The mass balance of a cold glacier: Merserve Glacier, south Victoria Land, Antarctica. [Union Géodésique et Géophysique Internationale. Associatiion Internationale d'Hydrologie Scientifique.] [International council of Scientific Unions. Scientific Committee on Antarctic Research. International Association of Scientific Hydrology. Commission of Snow and Ice.] International Symposium on Antarctic Glaciological Exploration (ISAGE), Hanover, New Hampshire, U.S.A., 3-7 September 1968, p. 429-46. [(Publication No. 86 [de I'Association Internationale d'Hydrologie Scientifique].)]

Calkin, P.E. 1974. Subglacial geomorphology surrounding the ice-free valleys of southern Victoria Land, Antarctica. Journal of Glaciology, Vol. 13, No. 69, p. 415-29.

Clark, S.P. 1966. Thermal conductivity. (In Clark, S.P., ed. Handbook of physical constants. Revised edition. New York, Geological Society of America, p. 121-30. (Geological Society of America. Memoir 97.))

Decker, E.R. 1978. Geothermal models of the Ross IslandDry Valley region. Dry Valley Drilling Project Bulletir No. $8, p .11$.

Decker, E.R., and Bucher, G.J. 1977. Geothermal studies in Antarctica. Antarctic Journal of the United States, Vol. 12, No. 4, p. 102-04.

Denton, G.H., and others. 1971. The late Cenozoic glacial history of Antarctica, by G.H. Denton, R.L. Armstrong, and M. Stuiver. (In Turekian, K.K., ed. The late Cenozoic glacial ages. New Haven and London, Yale University Press, p. 267-306.)

Drewry, D.J. 1982. Ice flow, bedrock, and geothermal studies from radio-echo sounding inland of McMurdo Sound, Antarctica. (In Craddock, C., ed. Antarctic geoscience. Symposium on Antarctic geology and geophysies, Madison, Wisconsin, U.S.A., August 22-27, 1977. Madison, University of Wisconsin Press, p. 977-83.)

Glen, J.W. 1955. The creep of polycrystalline ice. Proceedings of the Royal Society of London, Ser. A, Vol. 228, No. 1175, p. 519-38. 
Holdsworth, G. 1974. Meserve Glacier, Wright Valley, Antarctica. Part 1. Basal processes. Ohio State University. Institute of Polar Studies. Report No. 37 .

Hooke, R.L. 1976. Pleistocene ice at the base of the Barnes Ice Cap, Baffin Island, N.W.T., Canada. Journal of Glaciology, Vol. 17, No. 75, p. 49-59.

Hooke, R.L. 1977. Basal temperatures in polar ice sheets: a qualitative review. Quaternary Research, Vol. 7, No. 1, p. 1-13.

Hughes, T.J. 1971. Structural glaciology of Meserve Glacier. Phase 3. Antarctic Journal of the United States, Vol. 6, No. 4, p. 127-28.

Jones, A.S. 1978. The dependence of temperature profiles in ice sheets on longitudinal variations in velocity and surface temperature. Journal of Glaciology, Vol. 20, No. 82, p. 31-39.

Keys, J.R. Unpublished. Salts and their distribution in the McMurdo Sound region, Antarctica. [Ph.D. thesis, Victoria University of Wellington, 1980.]

Muiller, F. 1962. Zonation in the accumulation area of the glaciers of Axel Heiberg Island, N.W.T., Canada. Journal of Glaciology, Vol. 4, No. 33, p. 302-11.

Nye, J.F. 1951. The flow of glaciers and ice-sheets as a problem in plasticity. Proceedings of the Royal Society of London, Ser. A, Vol . 207, No. 1091, p. 554-72.

Paterson, W.S.B. 1981. The physics of glaciers. Second edition. Oxford, etc., Pergamon Press. (Pergamon International Library.)

Péwé, T.L., and Church, P.E. 1962. Glacier regimen in Antarctica as reflected by glacier-margin fluctuation in historic time with special reference to McMurdo Sound. Union Géodésique et Géophysique Internationale. Association Internationale d'Hydro- logie Scientifique. Commission des Neiges et des Glaces. Colloque d'obergurgl, 10-9-18-9 1962, p. 295-305. (Publication No. 58 de l'Association Internationale d'Hydrologie Scientifique.)

Philberth, K., and Federer, B. 1971. On the temperature profile and the age profile in the central part of cold ice sheets. Journal of Glaciology, Vol. 10, No. 58, p. 3-14.

Robin, G. de Q. 1955. Ice movement and temperature distribution in glaciers and ice sheets. Journal of Glaciology, Vol. 2, No. 18, p. 523-32.

Robinson, P.H. 1982. Temperate ice beneath the "polar" Taylor Glacier, Victoria Land, Antarctica. Annals of Glaciology, Vol. 3, p. 355. [Abstract.]

Robinson, P.H. Unpublished. An investigation into the processes of entrainment, transportation, and deposition of debris in polar ice, with special reference to the Taylor Glacier, Antarctica. [Ph.D. thesis, Victoria University of Wellington, 1979.]

Stern, T.A. 1978. Gravity survey of Taylor Glacier, Victoria Land, Antarctica. Victoria University of Wellington. Antarctic Data Series, No. 5.

Stuart, A.W., and Heine, A.J. 1961. Glaciological work of the 1959-60 U.S. Victoria Land traverse. Journal of Glaciology, Vol. 3, No. 30, p. 997-1002. Stuiver, M., and others. 1981. History of the marine ice sheet in West Antarctica during the last glaciation: a working hypothesis, by M. Stuiver, G.H. Denton, T.[J.] Hughes, and J.L. Fastook. (In Denton, G.H., and Hughes, T.J., ed. The last great ice sheets. New York, Wiley-Interscience, p. 319-436.)

Taylor, L.D. 1965. Glaciological studies on the South Pole traverse, 1962-1963. Ohio State University. Institute of Polar Studies. Report No. 17. 